\title{
NOTES ON A FOLIO FROM THE GULSHAN ALBUM IN THE COLLECTION OF THE NÁPRSTEK MUSEUM, PRAGUE
}

\author{
Adriana Stříbrná ${ }^{1}$
}

\begin{abstract}
In 2015 the Náprstek Museum, in cooperation with the National Library of the Czech Republic, carried out a conservation survey of two rare folios from the Gulshan Album of the Mughal emperor Jahāngīr which form part of the Náprstek Museum's Indian collection. During the survey an unknown signature by the painter Âqā Rezā was discovered in the border of one of them. The new finding was the impetus for this study, looking at the folio in more detail. In addition to the introductory part, which looks at the form and function of illustrated albums in the Mughal Empire, the study describes in detail both a miniature on one side of the folio and the calligraphy and border with human figures on the other side, and explains the relationship between them.
\end{abstract}

KEYWORDS: Gulshan Album - Miniature painting - Mughals - Calligraphy - Jahāngīr - Salìm

The Indian Collection of the National Museum - Náprstek Museum of Asian, African and American Cultures (hereafter the Náprstek Museum) in Prague contains two separate folios, which in the past belonged to an imperial album owned by the Mughal ruler Jahāngīr (1569-1627). They are considered masterpieces of Indian Islamic art. In particular the miniature of Ibrāhīm 'Adil Shāh II of Bijapur playing tanbur became a focus of art historians more than a half century ago and has been analysed many times in a number of publications. ${ }^{2}$ The second folio with a miniature depicting a young aristocrat with a hound did not get so much attention from experts. But recently the Náprstek Museum, in cooperation with the National Library of the Czech Republic, carried out a conservation survey of these two rare folios. During the survey an unknown signature by the painter Âqā Rezā was discovered in the border of one of them. This discovery provided the impulse for a new art historical research into this folio, the results of which are Summarized by the study below.

Imperial album, known in Persian as muraqqa', was a type of illustrated book favoured by rulers in Persia, Turkey, and India. Originally unrelated images such as miniatures, European engravings or beautiful calligraphies were mounted on each side of a single leaf and bound into an album. The symmetry of the pictures was very important when deciding how to put the images and calligraphy together. When the album was open, two pages with pictures, miniatures or prints always faced each other, while

1 Contact: Adriana Stříbrná, Naprstek Museum of Asian, African and American Cultures, Prague, Czech Republic; e-mail: adriana.stribrna@nm.cz. This work was financially supported by the Ministry of Culture of the Czech Republic (DRKVO 2019-2023 /19.III.c, National Museum, 00023272).

2 For example Hájek 1960; Knížková 1986; Skelton 2011. 
on both the next two pages there were ingeniously and symmetrically arranged calligraphies. The frames around the images and calligraphies, together with generously illuminated margins ( $h \bar{a} \operatorname{sh} \bar{i}$ ) became a way of achieving visual and thematic unity.

Many albums were created in Mughal India. The most important and most ornate of them is the Gulshan Album, which is kept in the Library of the Gulistan Palace in Teheran, the capital of Iran. The album was made for Mughal emperor Jahāngīr at the beginning of the $17^{\text {th }}$ century.

Hájek $^{3}$ mentions Jahāngīr's manuscript, according to which the Jahāngīr album was gradually put together between 1608 and 1614. However, Beach (2013, p. 469) states: 'The earliest date in the album that relates to its assembly is $1600 \ldots$ while the latest date found anywhere in the book (excluding its seals and library notes) is 1631-1632.' This suggests that the compilation of the album took a lot longer, and that it was completed or amended during the rule of Jahāngīr's successor Shāh Jahān (1592-1666), who ascended to the throne in 1628. Many of the miniatures and calligraphies used are considerably older, however, and this is also true of the folios in the Náprstek Museum.

In the $19^{\text {th }}$ century by that time two separate albums were bound together at the behest of Persian ruler Nāsir al-Dīn Shāh Qājār (1831-1896). One of these albums was known as Muraqqa'-i Gulistān, while the other part as Muraqqa'-i Gulshan. Both were kept in the Gulistan Palace. One of them belonged to the Royal Library of Gulistan Palace, while the other was in the personal possession of the Shah and was stored separately in the private part of the palace. ${ }^{4}$ We do not know how exactly the album fell into Nāsir al-Dīn Shāh's hands, but we know that he owned it from the time when he was a crown prince with his court in Tabriz. ${ }^{5}$ It could have been looted from Nādir Shāh Afshār's invasion of India in $1739^{6}$ like the famous Peacock Throne or the precious diamond Koh-i-Noor, or it could have been a royal gift. Unfortunately, the album did not stay as a whole for a long time.

Just as we can only speculate on how the Jahāngīr album passed into the hands of the Persian Shah, so we do not know for certain how two of its folios ${ }^{7}$ got into the collection of the Náprstek Museum in Prague. One possibility is that they were brought from Persia by Count Viktor Dubský of Třebomyslice (1834-1915), ${ }^{8}$ who was the AustroHungarian envoy to Persia from 1872 to $1876 .{ }^{9}$ What is certain is that further folios are scattered around galleries and museums all over the world. Outside Teheran the largest more comprehensive collection, which originally belonged to the same album, can be found in the State Library in Berlin. A total of twenty-five folios reached Germany via the Egyptologist Heinrich Ferdinand Karl Brugsch (1827-1894), who acquired them during his stay in Isfahan from 1860 to 1861 . He had travelled there with the Prussian diplomatic mission of Julius von Minutoli (1804-1860). ${ }^{10}$

\footnotetext{
3 Hájek 1960, p. 74.

4 Eslami 2012; Safarzadeh 2011, pp. 169.

5 Eslami 2012.

6 Hájek 1960, p. 11.

7 Náprstek Museum, inventory numbers A12182 and A12183.

8 Ohlídalová, Pospíšilová and Dřevíkovská 2016.

9 For more on Count Dubský see Bečka 2000.

10 Kühnel and Goetz 1926, p. 8.
} 
In 2015 a non-invasive conservation survey of the Náprstek Museum's two folios from the Jahāngīr album took place. This was because the folio with inventory number A12182, which contains a portrait of Ibrāhīm 'Adil Shāh II of Bijapur playing the tanbur was being prepared for transport to the exhibition Sultans of Deccan India, 1500-1700. Opulence and Fantasy, at the Metropolitan Museum of Art in New York City. As well as the folio destined for the exhibition, a conservation survey was also carried out on the second folio, with inventory number A12183 with a miniature of a young nobleman with a hound on one side. During the survey, an unknown inscription was discovered in the margin of the other side, the side without a miniature, next to one of the marginal figures. It came as a pleasant surprise that this inscription contained the easily-legible signature of the painter Āqā Rezā Heravī, which in Persian is, 'Murīd bā ikhlās shāh-e Salìm Āqā Rezā', and can be translated as, 'the Loyal Disciple of Shah Salìm Āqā Rezā'. The first part, expressing loyalty to Salìm, is written at the bottom edge of the stone, but the actual name, Āqā Rezā, lies under it. As thus executed, it is a typical signature for this painter. This discovery clearly proves that Āqā Rezā, an important miniaturist in Jahāngīr's workshop, is the author of the figures in the margin of this folio.

Each folio in Jahāngīr's album is cleverly made up of many visual elements, and there were always several people working on it. Some painters specialized in the main, large miniatures, other painters in the additional decorative panels, another one painted the gilded backgrounds to the margins and yet another painter filled them with human figures or brought them to life with coloured birds. The greatest attention is traditionally captured by the side of the folio whose central part consists of painted miniatures. For European viewers, the Islamic miniatures were easier to understand, thanks to their visuality, than the decorative calligraphic texts in an unknown alphabet on the other side. In some cases, the miniatures were complemented by prints of European origin, in other cases by panels with calligraphic or floral patterns, while sometimes only a thin frame divided them from the decorative margins. In order to see the folios in the way in which the author intended them to be perceived, however, it is not enough to perceive the picture in the miniature independently or to look only at one side of the folio. It is also important to look at the facing folio at the same time. Only if we look at two pages in the open album, we will perceive the entire composition as a whole, balanced and complete. We can reveal well-thought out overall composition with the central miniatures or calligraphies complemented by elements in the margins. The margins around the miniatures were usually filled with a gold decoration featuring plant and animal motifs, brought to life by various kinds of brightly coloured birds, while those around the calligraphies were enriched by human figures painted in soft colours.

Unfortunately, in the case of the pages from Jahāngīr's album that are scattered around world museums we can no longer gain the full impression from these ingenious compositions. This also applies to the two folios in the Náprstek Museum. Although at first sight, the composition of the two pages with miniatures is very similar - the inside, the pictorial part is in both cases made up of miniatures, to which are stuck in each case two smaller prints of European origin - if we take a closer look we will find that the decoration in the margins is entirely different. But this decoration, surrounding the different subjects of the central figural scenes, used to be the main unifying element. There is also a significant difference in the way in which the prints are framed. We can thus say for certainty that these two pages were not adjacent to each other in the album. 
The folio with inventory number A12183 is bearing a miniature featuring a young nobleman with a hound [Pl. 1]. The young man is sitting elegantly, with crossed legs, on the thin, bent trunk of a flowering tree. This miniature was first described by Hájek, ${ }^{11}$ who interpreted the depicted young patrician as Prince Salīm and the authorship ascribed to Āqa Rezā on the basis of art historical analysis of the artistic style. There is no other clue to determine the author, which makes this attribution of authorship debatable.

Prince Salim ascended the throne in 1605 at the age of thirty-six after the death of his father, Akbar. As ruler, he took on the name of Jahāngï. He had already tried to become an independent ruler and strengthen his power five years earlier, however. As Akbar's grand vizier Abu'l Fazl writes in the official chronicle Akbarnāma, Salìm rebelled against Akbar and went to Allāhābād, where he took land away from Akbar's vassals. With the money that he gained from the seizure of the Mughal provincial treasury, he founded his own ruling court and began to use the title pādishāh (emperor), which only the Mughal ruler Akbar was allowed to use (Beach, 2013, p. 446). He also attempted to bolster his ambition to rule by founding his own artistic workshop. Thanks to the painting workshop at his father's court, he knew the value of art and was clearly aware of the important role it played in legitimising the ruler's power. In addition to classic Persian book painting, he was also well-acquainted with European painting. Akbar's court was visited by immigrants from Persia, Jesuit missionaries and other Europeans, all of them seeking new opportunities in economically and culturally flourishing India. In his memoirs, Jahāngīr recounts how, while still Prince Salìm, he hired the Persian artist Āqā Rezā Heravi for himself. ${ }^{12}$ This artist's work is clearly reflected in the Gulshan album. In this early period, an album was created at the commission of Prince Salim and is today known as the Salim album. Its dimensions are smaller than the later album created for him when he was the ruler Jahāngïr. Some thirty miniatures, most often portraits, have been preserved from the Salīm album.

The young man is dressed in the rich clothes of an aristocrat. He is wearing a golden kaftan of silk brocade with short sleeves, and with long, false sleeves falling down along his arms. The design of the material is made up of plant rinceaux with flowers added. Several songbirds sit on the branches. In the place where the outline of the prince's calf can be seen under the material, the pattern creates a medallion with a palmette reminiscent of the pattern known as the Shäh 'Abbāsì motif, popular on Safavid and later Mughal carpets. There are further flowers belonging to the same range of means of expression. The style of clothing corresponds to fashions in Safavid Persia. The collar and the whole edge of the kaftan is underlaid with a thin strip of fine brown fur. The man's hair is covered by a fur cap decorated with a twig of jasmine, and there is a small golden brooch above the centre of his forehead. A black curl, a favourite symbol of beauty in classical Persian poetry, winds from his temple downwards, around a gold earring with a red stone and two pearls. On the palm of his left hand, a whitish cup without a handle is resting on a saucer. He has his thumb against its side so that it does not fall. Under his unbuttoned outer robe, we see a white shirt with a pinkish tinge and decorative frog fastening. He has greenish breeches held up by a belt with a gold buckle made of several parts, and with

11 Hájek 1960, p. 75.

12 Hájek 1960, p. 75; Beach 2013, p. 447. 
translucent Indian muslin flowing over them. The breeches end below the knees in high, turned-down riding boots with a flat sole.

Next to the young man stands a slender hunting hound. It is a long-haired grizzle saluki, an ancient breed used for centuries to hunt gazelles and hares all over the Greater Middle East, Central Asia, India, and China. From the stance of the elegant dog we can feel that it is restless. Its left front leg with a powerful paw is bent forward, but its head is turned towards its master. Its beautiful large eye is painted as if it belonged to a person. The upper lid is fringed with a row of lashes, instead of the lashes growing out of one place above the eye, as is the case with actual dogs. Its gaze is fixed on the distance, where we can imagine some sort of activity taking place outside the picture. Salukis are known for their excellent sight, which means they are able to see their prey a great distance away.

There are wild flowers growing in the ground around the prince's leg: a small poppy, a tall purple iris, a little yellow plant with star-shaped flowers, a blue iris, and another blue flower, reminiscent of the blue daisy (chicory). Above the man's head is a flock of six birds of various colours. The bark on the bent trunk on which the youth has sat down to rest is executed in an interesting way. It is not smooth, as tends to be the case in Persian and Mughal miniatures usually but has long strings of moss growing on it.

The young man depicted on folio A12183 corresponds to ideas of the ideal young nobleman as described in the etiquette manual Mìrzānāma. This covers all the aspects of being a proper mìrza (a high-born nobleman), including manners, dress and suitable food. It was written in Mughal India in the second half of the $17^{\text {th }}$ century, several decades after the Jahāngīr album was completed. We read that a mīrzā, 'should regard the beauty of flowers..., of the jewels, he should like rubies and pearls', ${ }^{13}$ and that, 'he should not wear flowers in his turban, as it is effeminate to do so... Occasionally, in privacy, he may put a bunch of nafarman flowers, which is like a plume of feathers, in the corner of his turban. ${ }^{\prime 14}$ Although the little bunch of flowers stuck in the cap of the young man from the miniature is not exactly the nâarmān (larkspur) recommended as a turban decoration by the Mìrzānāma, it is also not a single flower, which would be considered a typical sign of a passive love object equated with femininity.

A similar subject, in other words, a young man resting in natural surroundings and accompanied by a hunting dog is found among the miniatures from the Jahāngī album in the Berlin collection. ${ }^{15}$ Here the young man is sitting on a large boulder, in a similarly relaxed style with his legs crossed. Behind him, also, there is a flowering tree, and several birds fly above his head. Instead of a cup and saucer, however, he holds in his hand an open book, which he is reading. His short-haired saluki is lying comfortably on the ground, but is on guard, with its head erect and gaze focused on the distance in front.

On the A12183 it can be clearly seen that the miniature with the youth was considerably narrower before it was composed into the album. In order to fit the overall composition, two strips of paper were added down the longer sides, and it had to be painted further in order to achieve the necessary dimensions. The painter who carried out the montage followed on from the flowers in the original miniature, further developing and adding to their shape on the additional strips of paper. He also added two pale tufts

13 Ahmad 1975, pp. 104

14 Ahmad 1975, pp. 106.

15 Kühnel and Goetz 1926, p. 47. 
of grass in the upper part of the additional painting, but these are floating in the air somewhat, as if they were making an unsuccessful attempt to create a high horizon at the edges, or another ground in the picture.

Two pictures representing Taste (Gustus) [Pl. 2] from the Five Senses cycle and Grammar (Grammatica) [Pl. 3] from the Free Arts cycle originally printed by the German Renaissance artist Georg Pencz (c. 1500-1550) make a unified whole with the miniature. Both engravings are in the collection of, for example, the Metropolitan Museum of Art in New York City, which also makes them accessible on its website. ${ }^{16}$ There are a few differences in the execution of these two pictures on folio A12183 which suggest that they are not the original Pencz's prints. In particular, the inscription in the lower margin, the facial expression of the monkey, and the food arrangement on the plate in the hands of the figure representing the Taste are different. In the case of Grammar, the differences on the folio compared to the original can be seen in the features of the cupid and the female figure, the shape of her right sole, the execution of the letters and the shape of the cartouche on the head of the bench on which the personification of Grammar is sitting. The prints, from various cycles but here placed next to each other, are unified with the aid of an additionally painted line of columns, into an apparently connected space. A further unifying element is the framing around the prints and the miniature, consisting of several strips. The transition between the pictures and the frame itself consists of a border with a repeated rinceau pattern. ${ }^{17}$ The Gulshan Album is noted for its wide margins, which provide enough space for further painting. On the page of the folio where the main central motif is a miniature there is a lack of human figures in the margin of the motif. In our case there is a predominance of gold decoration on a brownish base. It shows a landscape overgrown with various shrubs and herbs, around which animals and birds move. In the lower part we see a lion biting deeply into the throat of an antelope that it has just hunted down, while another antelope has managed to escape. A small fox is also escaping. To the right of the miniature two ibex or wild goats are courting, and in the upper part we see the legendary bird simurgh flying after a flock of waterfowl. While the simurgh is drawn using only a gold line, the other birds are alive with colours. It is thus easy to identify ducks, cranes, and the coloured quails popular in Asia.

On the recto of the folio, the centrepiece is the calligraphy signed, 'Mìr 'Ali al-Faqìr' [Pl. 4]. This is how the calligrapher Mīr 'Alī Heravī signed himself. A considerable number of his works are to be found in the Gulshan Album. A representative of the Herat school, he created calligraphy from the end of the $15^{\text {th }}$ century until 1544-1545 in courts in Timurid Herat and later Shaybanid Bukhara. He was a master of nastaliq lettering and was a highly-rated calligrapher both in Iran and India. Although he never visited Mughal India, he had a considerable influence on its calligraphy. This happened through his son, Mīr Muhamad Bāqir, who trained with his father and later emigrated to India. It seems to have been thanks to him that the Mughal court received a large

16 Pencz, G. Taste (Gustus), from The Five Sences [Engraving]. The Metropolitan Museum of Art, New York; for reproduction see The Met Collection, Taste (Gustus) Available at: https://www.metmuseum. org/art/collection/search/432533. Pencz, G. Grammar (Grammatica), from the Liberal Arts [Engraving]. The Metropolitan Museum of Art, New York; for reproduction see The Met Collection, Grammatica, from Liberal Arts. Available at: https://www.metmuseum.org/art/collection/search/432542.

17 For more on the issue of European prints and paintings used in the Jahāngīr album, with examples of further graphic art by Pencz from the same cycles see Beach 1965. 
number of works from Mīr Alī Haravī, which were used in albums put together for Jahāngīr and his successor to the throne, Shāh Jahān. ${ }^{18}$ As well as being an excellent calligrapher, he was also a poet, composing short poetic form qit'a. The verses from the folio A12183 appear to have been a demonstration not just of his calligraphic art, but also of his poetic skill.

In the upper row of the calligraphy is one of God's beautiful names, hu al-mu'iz, which may be translated as, 'He (is) the Honorer'. ${ }^{19}$ The following couplet has a mystical character and this beautiful name of God appears in it: 'Rasìdanat chu qudüm-e sìyām mubārak | Chu subh-e eid jamālat mu'iz u mut(a)bārak.' An English translation might be: 'Your return is blessed like the fasting coming back again | Like a feast-day morning your splendour is honourable and holy.' The couplet relates to an important aspect of the religious life of a Muslim believer, the compulsory fast during the month of Ramadan, which is a way of growing closer to God. The human figures in the margin around these calligraphic lines illustrate their contents. In a landscape full of rocks, bushes and little trees we see men in various situations connected with the period of religious fasting. A bearded man in the upper right-hand corner is kneeling on a prayer carpet with his hands in the gesture that ends the namāz prayer [Pl. 5]. In the upper lefthand corner is a youth dressed in the Indian jāma robe, with open hands next to each other raised to the heaven, to which his gaze is also directed, as if he were asking God to accept his fastIn the bottom left-hand corner, an almost naked figure stands with folded hands [Pl. 6]. He is recognisable as an ascetic, who has given up worldly goods. However, his figure, wrapped in a loincloth, is not like that of the gaunt bodies of the ascetics that are usually to be found in Persian and Mughal miniatures. His muscular and well-fed body is more reminiscent of the Renaissance ideal of masculine beauty. Furthermore, the way in which his hands are folded corresponds more to Christian than to Muslim prayer. It is therefore possible that the painter was inspired by one of the European works that found their way to the Mughal court with the Jesuits and other Europeans. In the opposite bottom corner sits a further ascetic [Pl. 7]. He is wearing a flowing robe, and his left hand is leaning on the branch that is used by mendicant monks as a seat or an arm rest. The aim of his stand is not entirely clear, but we may consider it part of the monk's equipment. The pose in which the man is sitting once again suggests the direct influence of Renaissance and Mannerist painting. The role of the figure painted to the left of the calligraphy is much clearer. It is a man dressed in a loose robe [Pl. 8]. Next to him lies a dish for food, and on the fire in front of him is a large kettle in which food seems to be being prepared for the iftār, the first meal in the evening with which believers fortified themselves during the hours when the fast was interrupted. The cook is watching the fireplace between two stones, and it is here that the signature of the miniaturist Āqā Rezā is hidden.

\section{Conclusion}

Thanks to the growing accessibility and perfection of modern technologies that help us examine in detail historical museum items with the aid of non-invasive methods, it is possible to gain new information even today about works that were examined in the

18 Soucek 1987, p.167.

19 Haeri 2018, p.74. 
past, but visually rather than using the methods of exact science. Visual examinations meant that some small details were easily overlooked. This is the case of the folio from the Náprstek Museum, where thanks to the discovery of the signature of the painter Âqā Rezā during conservation research using a microscope with a high magnification, it has proven possible to establish with certainty the authorship of the figures in the margins. These human figures do not appear in the margins by chance, but have an important role to play, illustrating the content of the calligraphically-executed verses in the centre of the folio by Mīr Alī Heravī. A further significant discovery is that the pictures that have until now been described as European prints differ considerably from the originals in their execution. It is thus possible to consider that they are Mughal copies of Pencz's originals. It is not the ambition of this study to answer all the questions that we ask about the Mughal folios from the Indian collection of the Náprstek Museum and to determine the authorship of the miniatures. It should, however, act as an introduction to their further detailed study.

\section{Literature:}

Ahmad, A. (1975). The British Museum Mīrzānāma and the Seventeenth Century Mīrzā in India. Iran, 13, pp. 99-110.

Beach, M. C. (1965). The Gulshan Album and Its European Sources. Bulletin of the Museum of Fine Arts, 63(332), pp. 63-91.

Beach, M. C. (2013). The Gulshan Album and the Workshops of Prince Salim. Artibus Asiae, 73(2), pp. 445-477.

Bečka, J. (2000). První rakousko-uherský vyslanec v Íránu. Nový Orient, 55(5), pp. 179-181.

Eslami, K. (2012). Golšan Album. [online] Encyclopædia Iranica. Available at: https:// iranicaonline.org/articles/golsan-album. [Accessed on 1 June 2020].

Haeri, F. S. (2018). Calling Allah by His most beautiful names. Zahra Publications.

Hájek, L. (1960). Indian Miniatures of the Moghul School. London.

Knížková, H. (1989). Notes on the Portrait of Ibrahim 'Adil Shah II of Bijapur in the Naprstek Museum, Prague. In: R. Skelton, ed., Facets of Indian Art. London, pp. 116-123.

Kühnel, E. and Goetz, H. (1926). Indian Book Painting from Jahangir's Album in the State Library in Berlin. London.

Losty, J. (1985). The 'Bute Hafiz' and the Development of Border Decoration in the Manuscript Studio of the Mughals. The Burlington Magazine, 127(993), pp. 855-871.

Overton, K. (2011). 'Ali Riza (The Bodleian painter). In: M. Beach, B. N. Goswamy and 
Fischer, E., eds., Masters of Indian painting I. 1100-1650. Zurich, pp. 375-390.

Ohlídalová, M., Pospíšilová, D. and Dřevíkovská, J. (in print). Průzkum dvou miniatur $z$ Džahángírova alba z Indické sbírky Náprstkova muzea. Sborník z XVI. semináře restaurátorů a historikü, Opava 2016.

Overton, K. (2016). Book Culture, Royal Libraries, and Persianate Painting in Bijapur, Circa 1580-1630. Muqarnas, 33, pp. 91-154.

Safarzade, N. (2011). The History of the Muraqqa'i Gulshan. Artibus Asiae, 71(1), pp. 163-172.

Seyller, J. (1995). Farrukh Beg in the Deccan. Artibus Asiae, 55(3/4), pp. 319-341.

Skelton, R. (2011). Farrukh Beg in the Deccan: An Update. In: H. N. Najat and M. Sardar, eds, Sultans of the South: Arts of Indian Deccan Courts, 1323-1687. New York, pp. 12-25.

Soucek, P. (1987). Persian Artists in Mughal India: Influences and Transformations. Relation between calligraphies and figures in margins. Muqarnas, vol. 4, pp. 166-181.

Soucek, P. P. (2011) Āqā Reżā Heravī. [online] Encyclopædia Iranica. Available at: http:// www.iranicaonline.org/articles/aqa-reza-heravi. [Accessed on 30 June 2020].

Swinton, A. (2001). A New Source for Albums of Indian Miniatures in William Beckford's Collection Lucian Harris. The Burlington Magazine, 143(1179), pp. 360-366.

Verma, S. (1979). Margin-painting in Medieval Indian Art. Proceedings of the Indian History Congress, 40, pp. 460-466.

The Metropolitan Museum of Art, (n.d.) Art Collection. [online] Available at: https:// www.metmuseum.org/art/collection [Accessed on 20 June 2020]. 


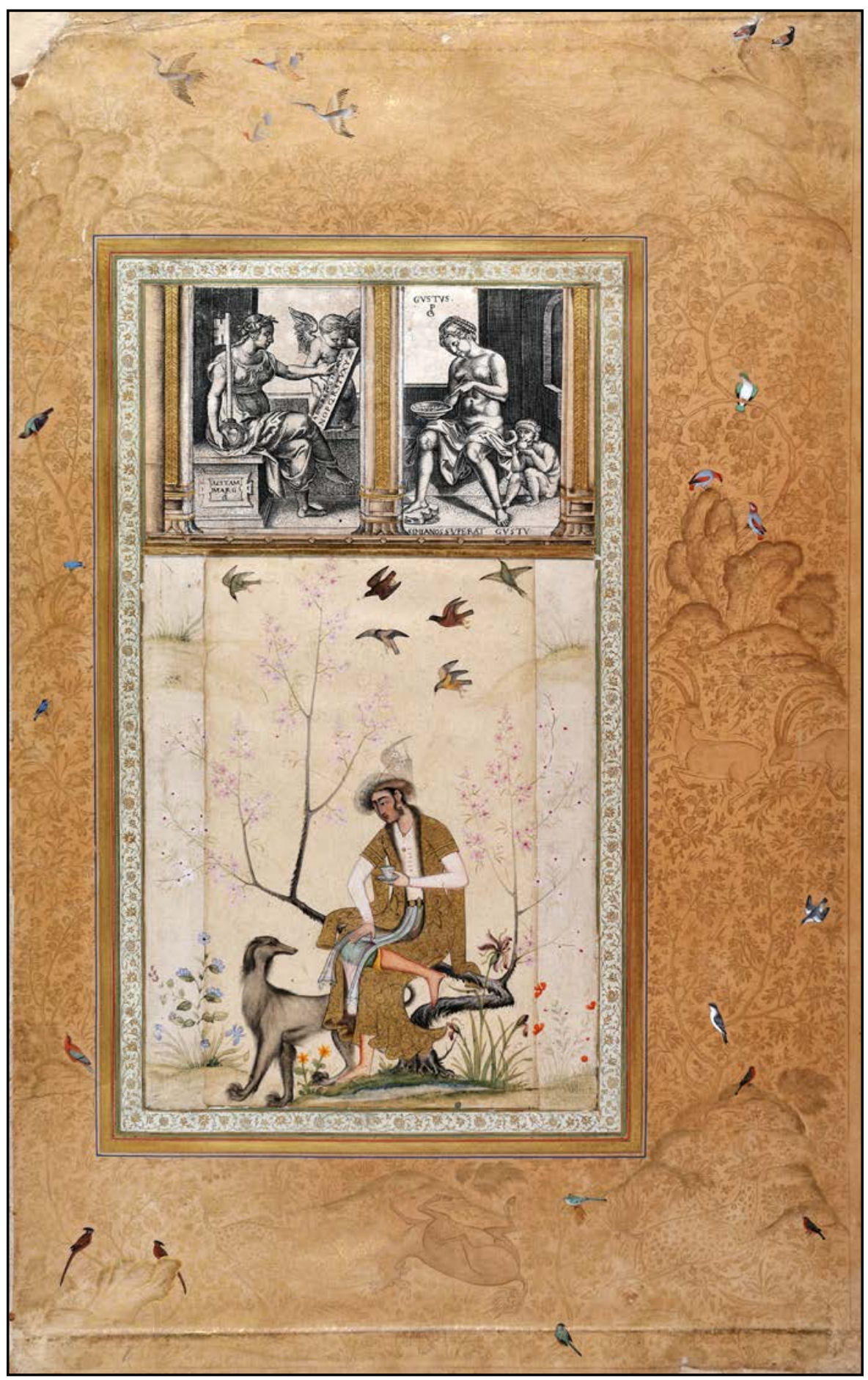

Pl. 1. Portrait of a young nobelman with his hound. Folio from the Gulshan Album (verso), Inv. No. A12183. (Photo: J. Vaněk, 2021) 


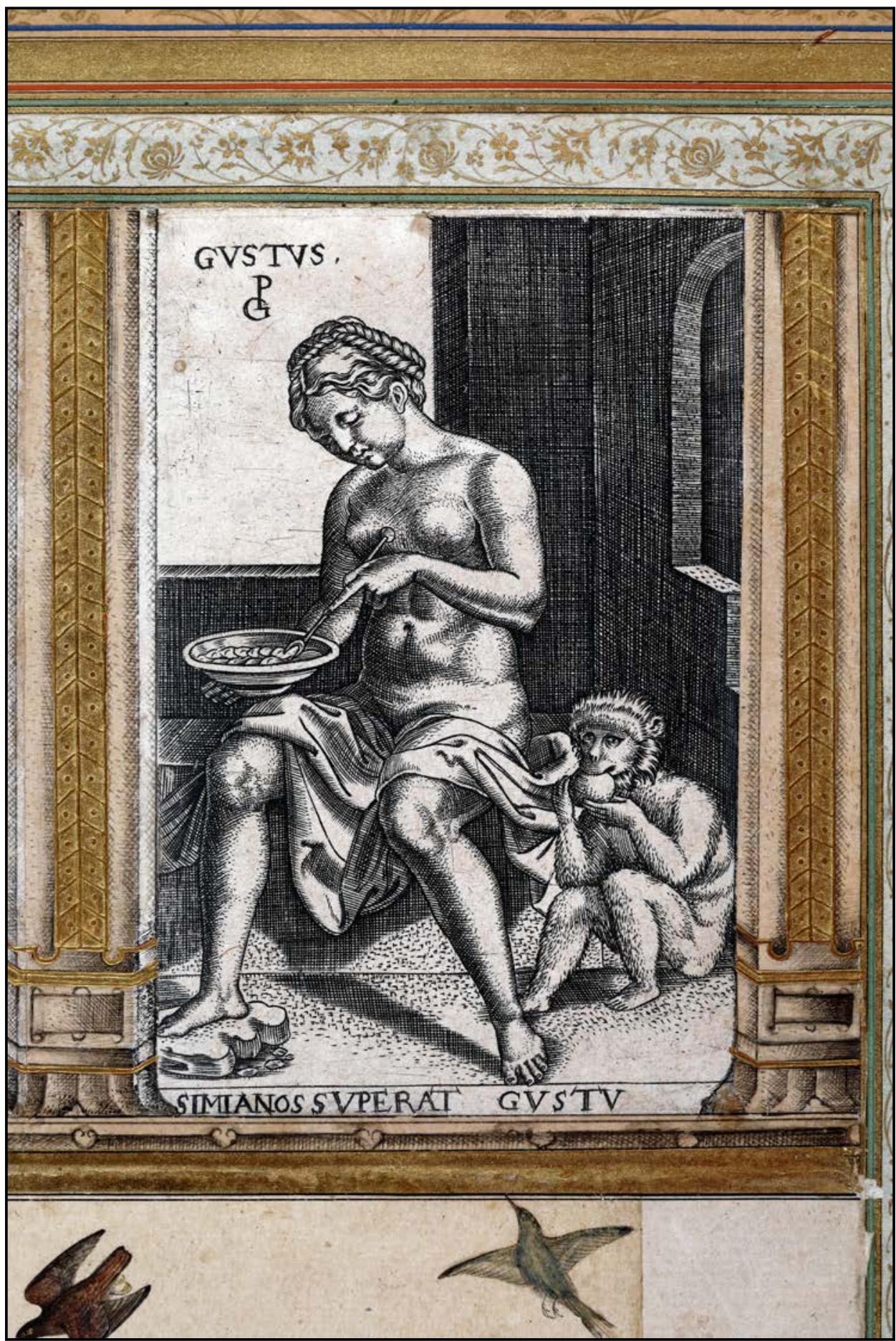

P1. 2. Taste (Gustus). Detail of the folio (verso), Inv. No. A12183.

(Photo: J. Vaněk, 2021). 


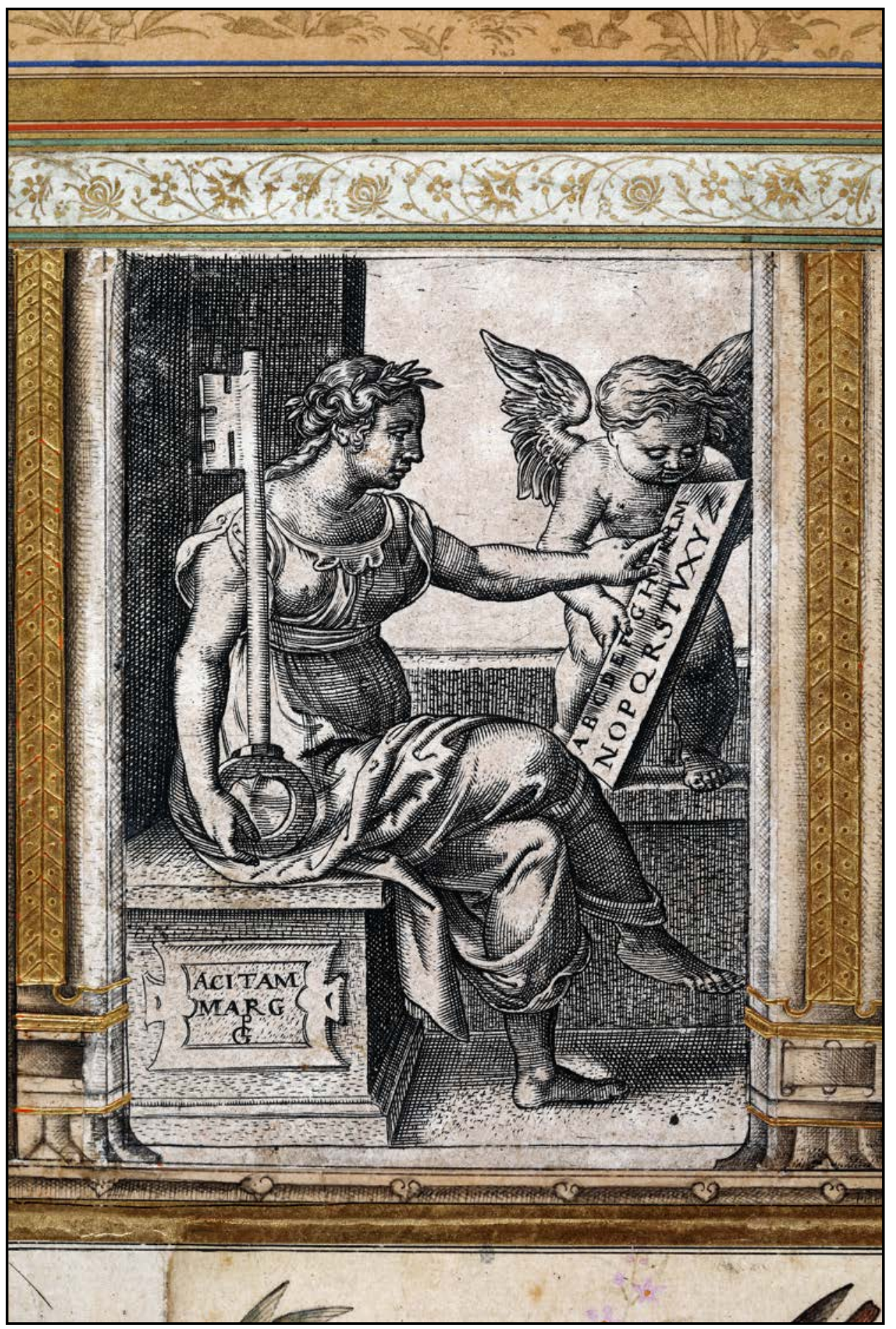

Pl. 3. Grammar (Grammatica). Detail of the folio (verso), Inv. No. A12183. (Photo: J. Vaněk, 2021). 


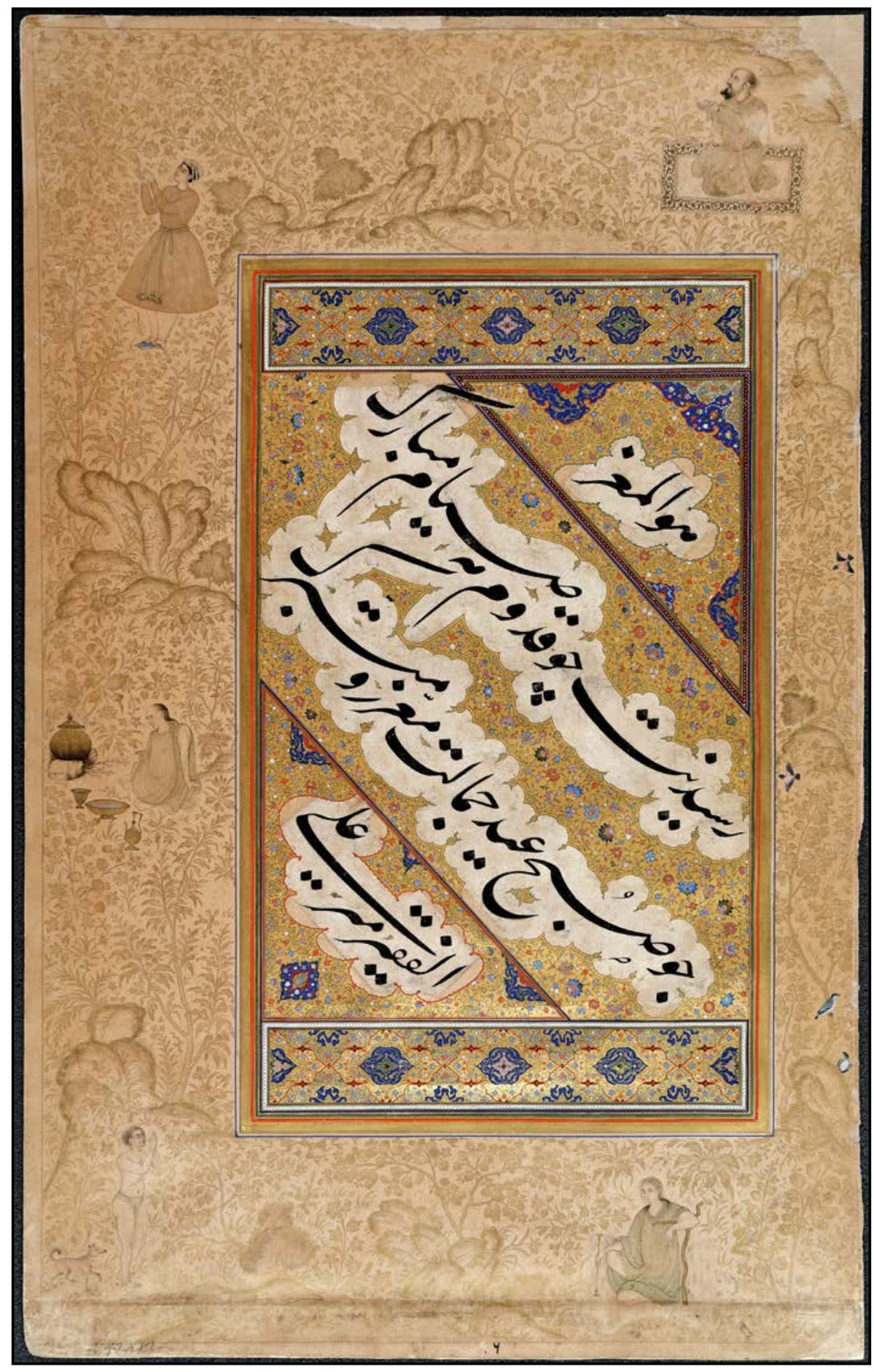

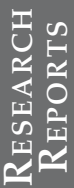

Pl. 4. Mìr 'Alì Heravī, Calligraphy. Folio from the Gulshan Album (recto), Inv. No. A12183. (Photo: J. Vaněk, 2021). 


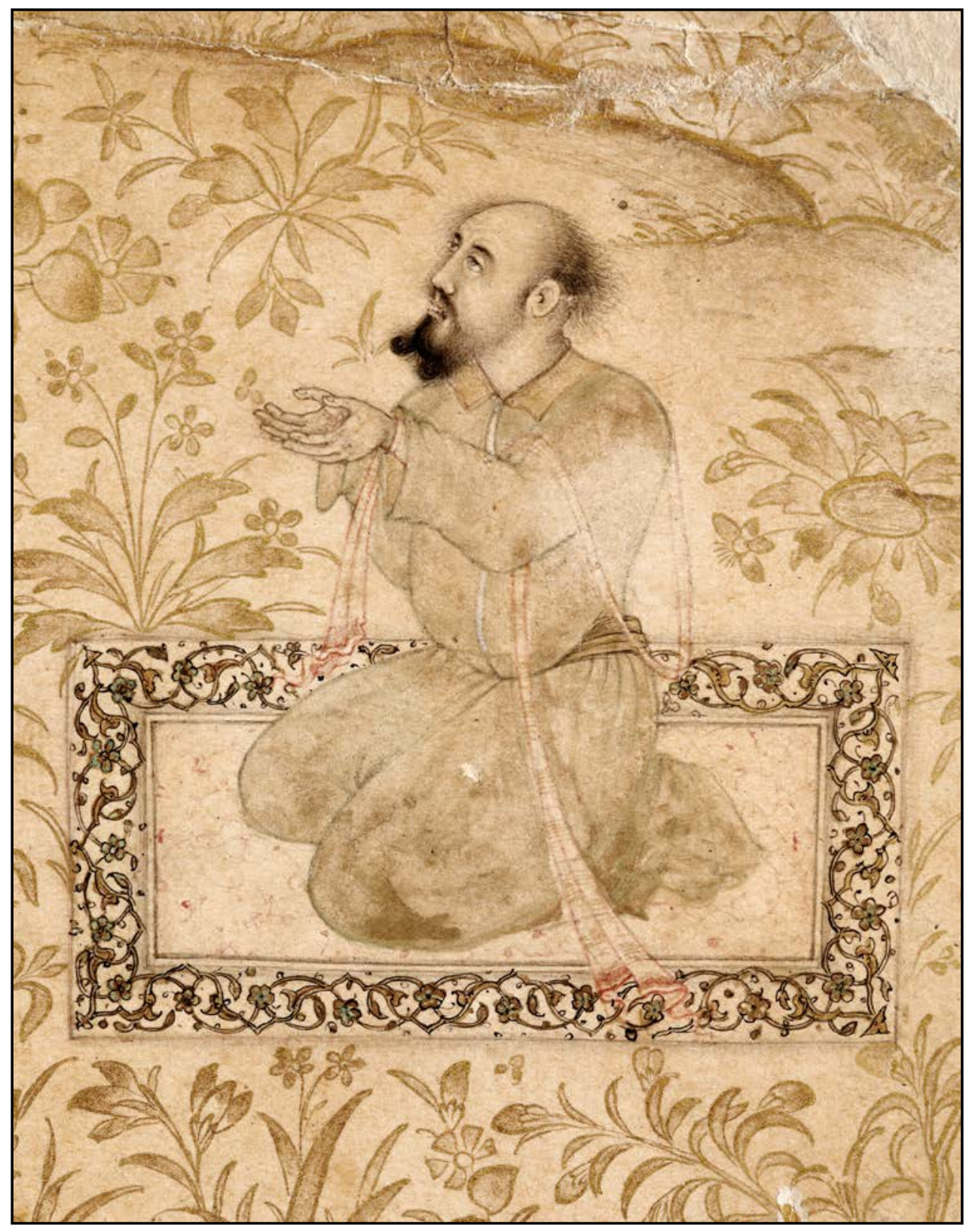

Pl. 5. Āqā Rezā, Muslim performing a prayer. Detail of the figural border on the recto of the folio, Inv. No. A12183. (Photo: J. Vaněk, 2021). 


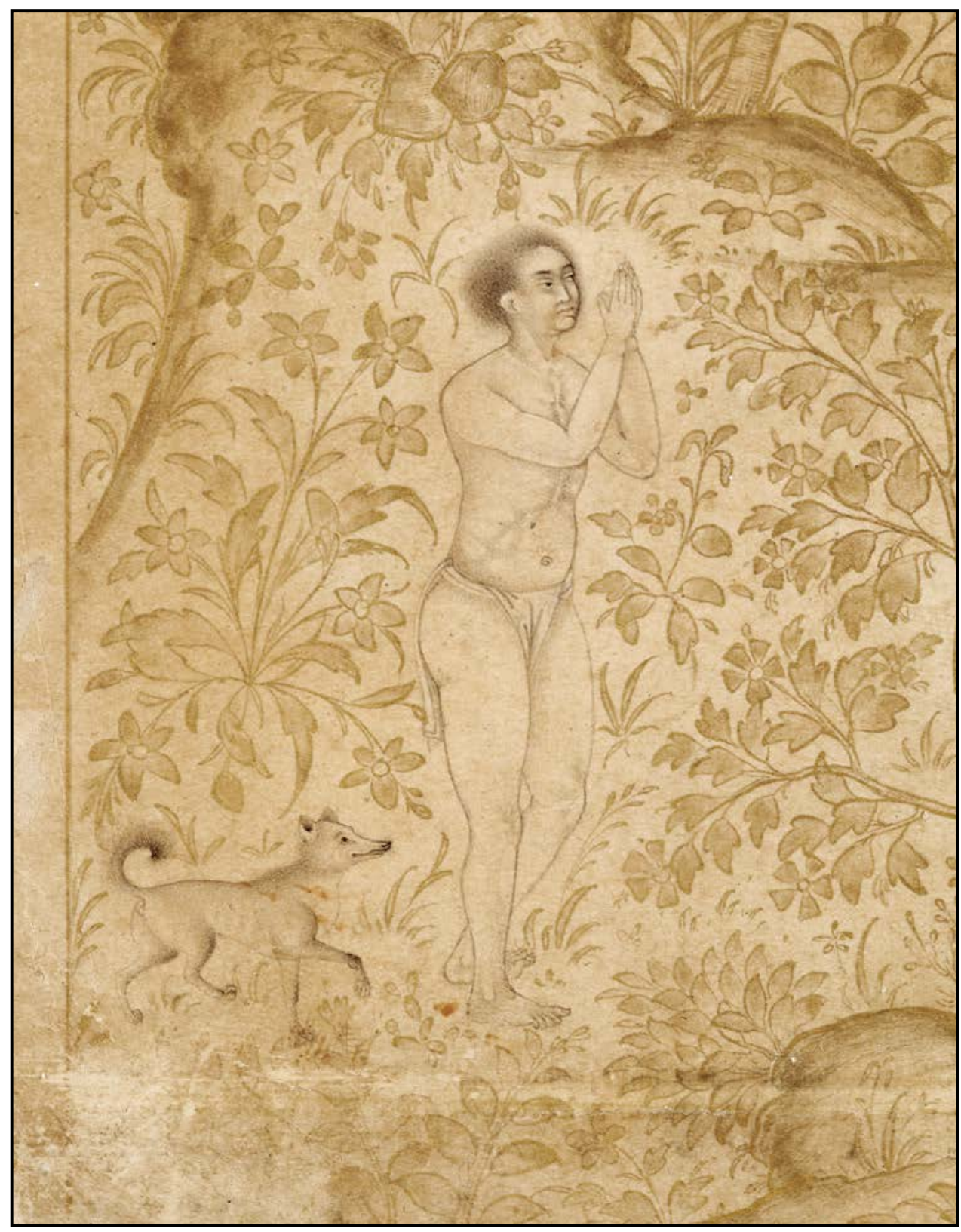

Pl. 6. Āqā Rezā, Ascetic man praying. Detail of the figural border on the recto of the folio, Inv. No. A12183. (Photo: J. Vaněk, 2021). 


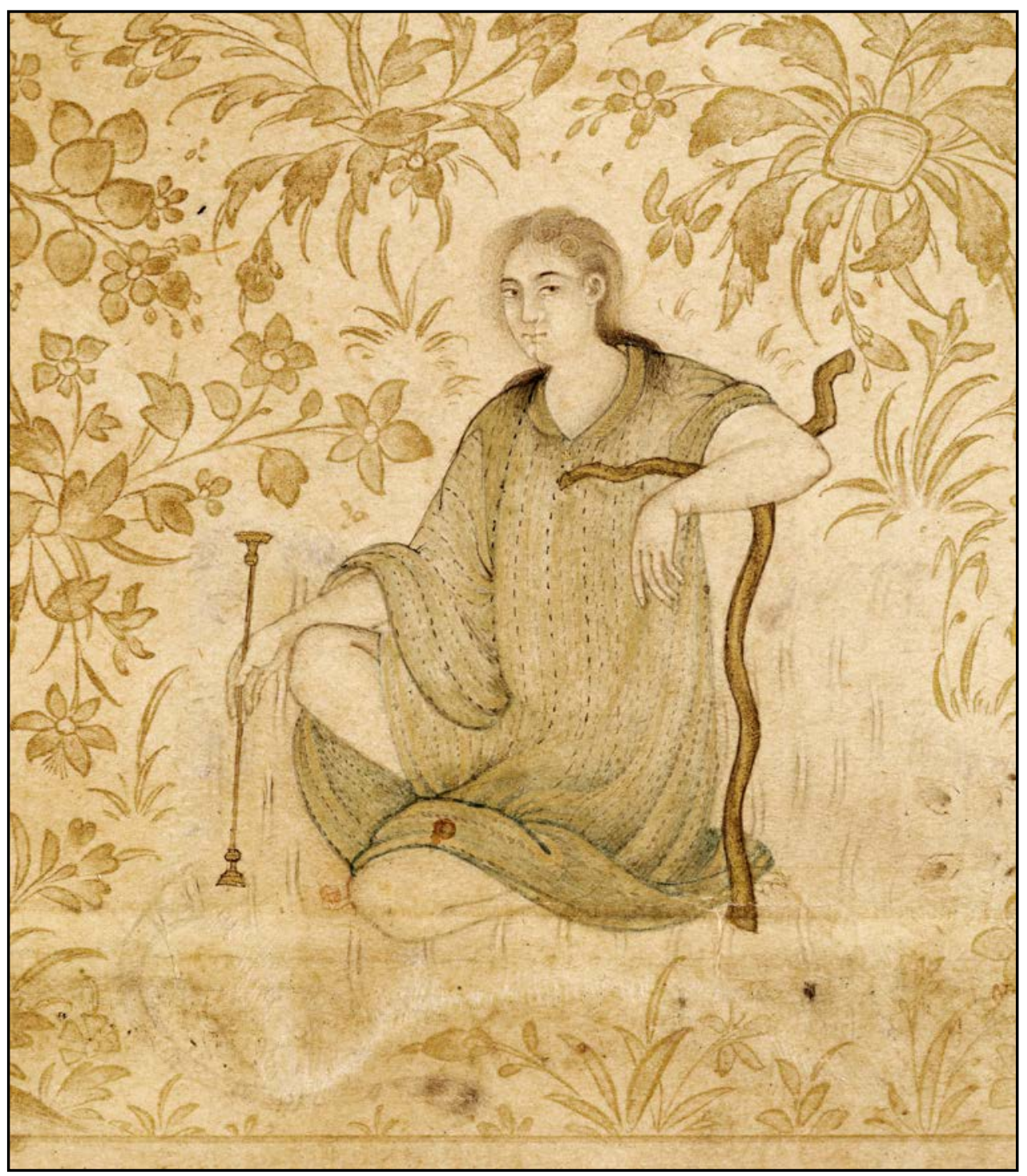

Pl.7. Āqā Rezā, Mendicant with an armrest crutch. Detail of the figural border on the recto of the folio, Inv. No. A12183.

(Photo: J. Vaněk, 2021). 


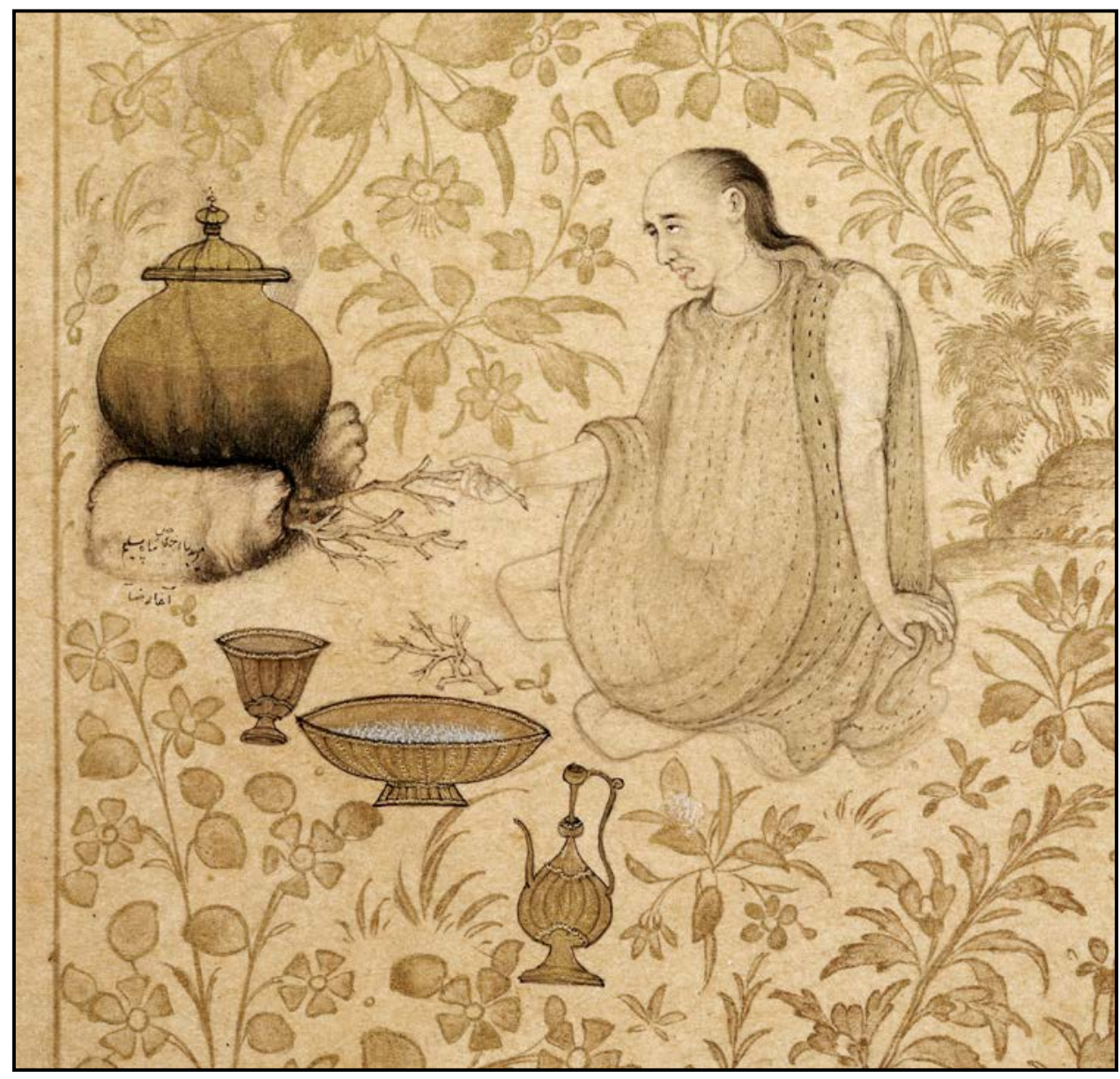

Pl. 8. Āqā Rezā, Man cooking a meal. Detail of the figural border on the recto of the folio, Inv. No. A12183.

(Photo: J. Vaněk, 2021). 